\title{
INFLUENCE OF MELATONIN ON THE ACTIVITY OF MAIN ENZYMES OF CORI CYCLE IN SKELETAL MUSCLES, HEART, LIVER AND KIDNEYS OF ALLOXAN-INDUCED DIABETIC RATS
}

\author{
Oleksandra Yu. KUSHNIR ${ }^{1 凶}$, Iryna M. YAREMIII ${ }^{1}$, Inna G. KYSHKAN ${ }^{1}$, Kyrylo A. PANTSIUK ${ }^{1}$, \\ Iryna D. VIZNIUK ${ }^{1}$ \\ ${ }^{1}$ Higher State Educational Establishment of Ukraine "Bukovinian State Medical University", Chernivtsi, \\ Ukraine
}

Received 5 Febr 2019, Accepted 14 Apr 2019

https://doi.org/10.31688/ABMU.2019.54.2.06

\begin{abstract}
Introduction. Melatonin, a potent antioxidant agent, is essential for glucose homeostasis.

The objective of the study was to determine the influence of melatonin on basal levels of glucose in blood, activities of glucose-6-phosphatase in kidney and liver, pyruvate kinase in muscles and heart, content of glycogen in muscles and heart of rats with alloxan-induced diabetes.
\end{abstract}

Materials and methods. Diabetes was induced in male Wistar rats by single intraperitoneal injection of alloxan monohydrates $(170 \mathrm{mg} / \mathrm{kg})$. Four days after diabetes induction, rats were divided into diabetic and melatonin-diabetic groups $(10 \mathrm{mg} / \mathrm{kg}$ «Sigma» USA, daily and intraperitoneal for 14 days starting from the $5^{\text {th }}$ day).

Results. Melatonin injections caused normalization of the elevated serum glucose level in diabetic group of rats compared with basal glucose level before treatment. The activity of pyruvate kinase in muscle and heart tissue of diabetic animals was $45 \%$ and $63 \%$

\section{Résumé}

L'influence de la mélatonine sur l'activité des enzymes principales du cycle de Cori dans les muscles du squelette, le coeur, le foie et les reins de rats avec diabète induit par l'alloxane

Introduction. La mélatonine, un puissant agent antioxydant, est essentielle à l'homéostasie et à la régulation du glucose.

L'objectif de l'étude a été de déterminer l'influence de la mélatonine sur les taux basaux de glucose dans le sang, les activités de la glucose-6-phosphatase dans les reins et le foie, la pyruvate-kinase dans les muscles et le cour, la teneur en glycogène dans les muscles et le cœur de rats diabétiques à l'alloxane.

Matériaux et méthodes. Le diabète a été provoqué chez des rats Wistar mâles par voie intrapéritonéale avec une injection unique d'alloxane (170 $\mathrm{mg} / \mathrm{kg}$ ). Quatre jours après l'induction du diabète, les rats ont été divisés en groupes diabétique et diabétique à la mélatonine (10 mg / kg «Sigma» USA, quotidiennement 
less than in control groups, respectively. Regarding kidney and liver of diabetic rats, the activity of glucose-6-phosphatase was increased in average by $148 \%$ compared with control value. The glycogen content in the heart and skeleton muscles of diabetic animals was reduced in average by $20 \%$ compared with the control. Melatonin restored all these indexes back to normal level.

Conclusions. These findings suggested that melatonin restored the events in Cori cycle by possible activation of glycolysis in skeletal and heart muscles and normalization of gluconeogenesis in liver and kidneys.

Keywords: alloxan-induced diabetes mellitus, melatonin, carbohydrate metabolism.

Abbreviations: BG - basal glucose, G-6-Ph-ase - glucose-6-phosphatase, PK - pyruvate kinase, DM - diabetes mellitus. et par voie parentérale pendant 14 jours à partir du 5ème jour).

Résultats. Les injections de mélatonine ont entraîné une normalisation de la glycémie élevée chez les rats diabétiques par rapport à la glycémie avant le traitement. L'activité de la pyruvate-kinase dans les tissus musculaires et cardiaques des animaux diabétiques est inférieure de $45 \%$ et $63 \%$ inférieure à celle du groupe témoin. Selon les résultats obtenus dans les reins et le foie de rats diabétiques, l'activité de la glucose-6-phosphatase a été augmentée en moyenne de 148\% par rapport à la valeur du contrôle. Nous avons constaté une réduction de $20 \%$ de la teneur en glycogène dans le cœur et les muscles des animaux diabétiques par rapport au témoin. La mélatonine a restauré tous ces indices au niveau normal.

Conclusions. Ces résultats suggèrent que la mélatonine a restauré les événements du cycle de Cori par l'activation possible de la glycolyse dans les muscles squelettiques et cardiaques et la normalisation de la gluconéogenèse dans le foie et les reins.

Mots-clés: diabète sucré induit par l'alloxane, mélatonine, métabolisme des glucides.

tissue involved in maintaining glucose homeostasis under insulin-stimulated conditions. Type 1 diabetic subjects without insulin treatment display a dramatic loss of muscle, which leads to higher blood glucose concentration, resulting in a vicious cycle ${ }^{3}$.

Melatonin (N-acetyl-5-methoxytryptamine) is the major product of the pineal gland, which functions as a regulator of sleep, circadian rhythm, and immune function. Melatonin and its metabolites have potent antioxidant/anti-inflammatory properties, which have proven to be highly effective in a variety of disorders linked to inflammation and oxidative stress ${ }^{4,5}$. Melatonin not only neutralizes reactive oxygen species (ROS), but also acts through the stimulation of several antioxidative enzymatic systems and stabilizing cell membranes ${ }^{6}$.

The Cori cycle (Fig. 1), named after its discoverers, Carl Ferdinand Cori and Gerty Cori, refers to the metabolic pathway in which lactate produced by anaerobic glycolysis in the muscles moves to the liver and is converted to glucose, which then returns to the muscles and is metabolized back to lactate?

This cycle of substrate fluxes, simplified as plasma glucose ->> muscle glycogen ->> plasma lactate ->> liver glycogen --> plasma glucose, is important in the redistribution of carbohydrate fuels in some species and is discussed here in relation to the role of melatonin.

Figure 2 presents the substrate contribution to renal gluconeogenesis as measured using 


\section{Recycling Pathways between Muscle and Liver}

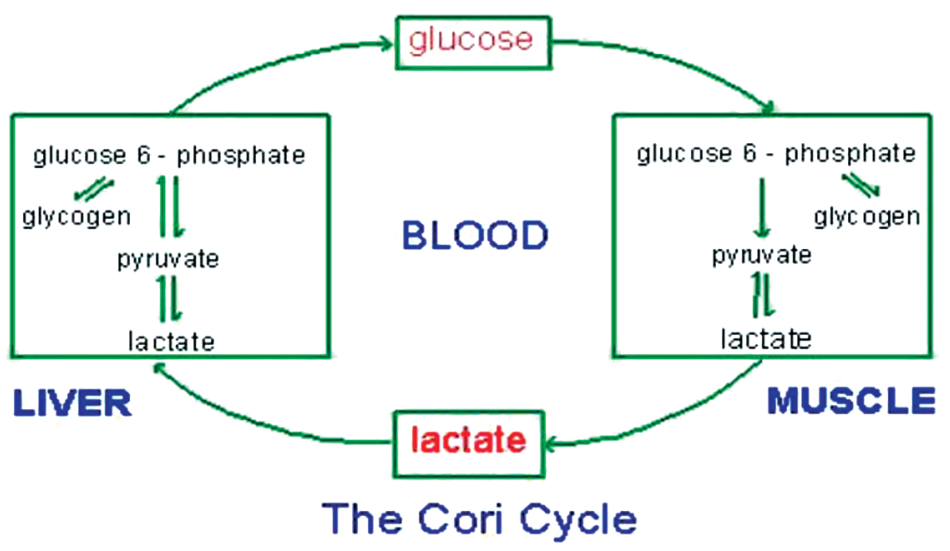

Figure 1. The Cori cycle

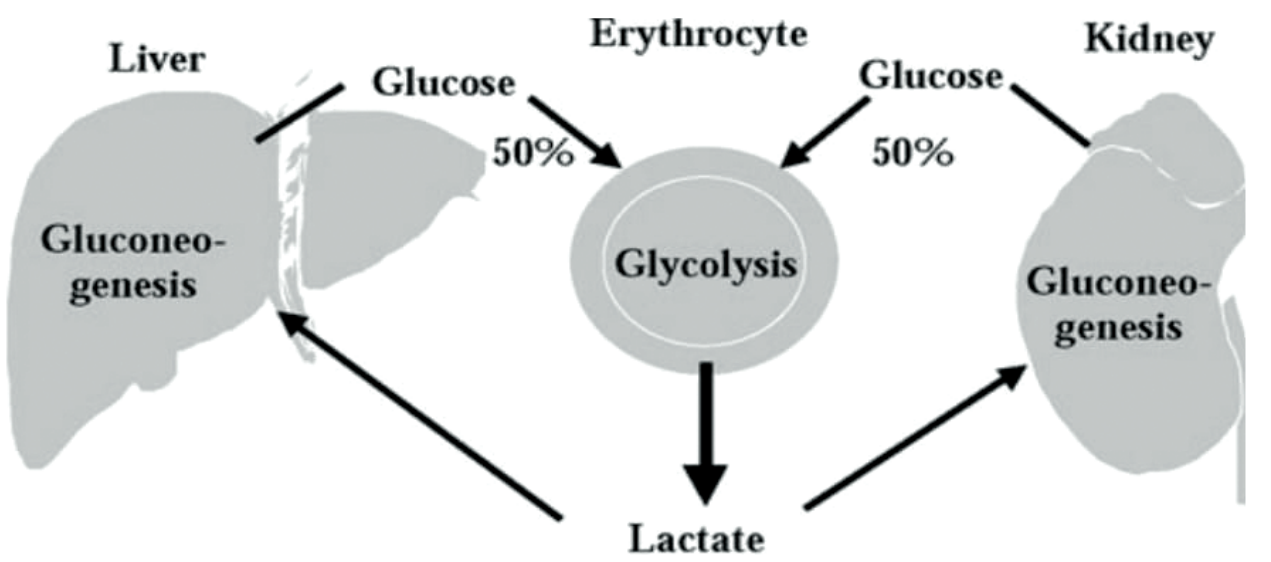

Figure 2. The substrate contribution to renal gluconeogenesis.

arteriovenous renal glucose and substrate balances together with renal glucose release measurement using deuterated glucose dilution. According to these data, lactate accounted for approximately $50 \%$ of renal gluconeogenesis. It can be calculated that renal glucose release from lactate is equivalent to $50 \%$ of overall lactate conversion to glucose. These data underline the major role of the kidneys in the Cori cycle. One-half of glucose production within the Cori cycle actually takes place in the kidney ${ }^{8}$.

Pyruvate- kinase (PK, EC 2.7.1.40) is the enzyme that catalyzes the final step of glycolysis 9

Glucose-6-phosphatase (G-6-Phase, EC 3.1.3.9) is an enzyme that hydrolyzes glucose 6-phosphate, resulting in the creation of a phosphate group and free glucose. Glucose is then exported from the cell via glucose transporter membrane proteins. This catalysis completes the final step in gluconeogenesis and therefore plays a key role in the homeostatic regulation of blood glucose levels ${ }^{10}$.
The influence of melatonin on the activities of PK and G-6-Phase in skeletal muscles, heart, liver and kidneys as well as on the content of glycogen in heart and muscles of alloxan diabetic rats is poorly understood. The present study evaluated whether melatonin administration would have protective effect against alloxan-induced changes in the Cori cycle.

The obJective OF THE STUdy was to determine the influence of melatonin on basal levels of glucose (BG) in blood, activities of G-6-Phase in kidney and liver, $\mathrm{PK}$ in muscles and heart, content of glycogen in muscles and heart of alloxan diabetic rats.

\section{Materials ANd Methods}

The research was performed in compliance with the Rules of the work using experimental animals (1977) and the Council of Europe Convention on the Protection of Vertebrate Animals used 


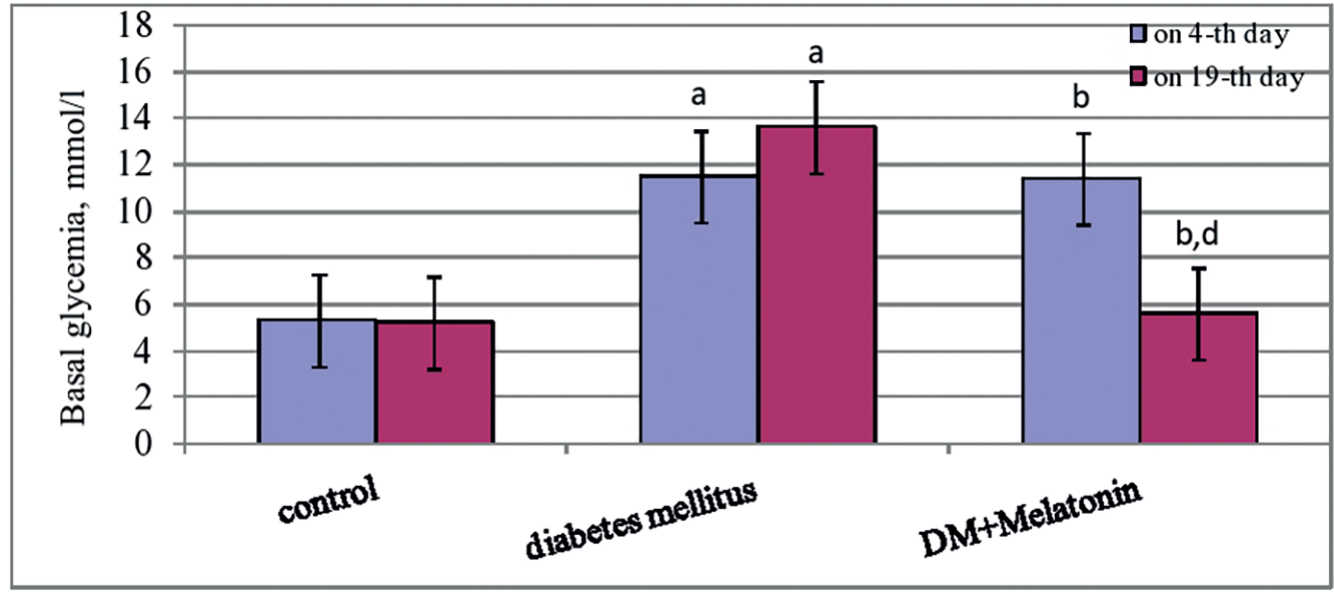

Figure 3. The level of basal glycemia $(\mathrm{mmol} / \mathrm{l})$ in blood of rats, $(n=6, x \pm S x)$ : 1. a, $b, c-$ changes are reliable $(p \leq 0,05)$. 2. a - concerning intact rats (control); $\mathrm{b}$ - concerning rats with diabetes mellitus; $\mathrm{c}$ - concerning indices on the $4^{\text {th }}$ day.

in experiments and other scientific purposes (Strasbourg, 1986), according to directions of International Committee of Medical Journals Editors (ICMJE), as well as "Bioethical expertise of preclinical and other scientific research conducted on animals" (Kyiv, 2006). Diabetes was induced in male Wistar rats by single i.p. injection of alloxan $(170 \mathrm{mg} / \mathrm{kg})^{11}$. Four days after diabetes induction, rats were divided into diabetic (DM) and DM +melatonin group $(10 \mathrm{mg} / \mathrm{kg}$ «Sigma» USA, daily and orally for 14 days starting from the $5^{\text {th }}$ day). Rats with $\mathrm{DM}$ are characterized by $\mathrm{BG} \geq 8.0 \mathrm{mmol} / \mathrm{L}$. Blood was taken from the tail vein in the $4^{\text {th }}$ and $19^{\text {th }}$ day, the BG level was evaluated with the use of OneTouchUltra (LifeScan, USA). Animals were sacrificed on the $19^{\text {th }}$ day from the beginning of the experiment, in accordance with the ethical treatment of animals. The rectus femoris muscle tissue, heart, kidney and liver were quickly removed, rinsed in saline, blotted, weighed and homogenized. The homogenate, $5 \%$ in ice-cold $0.25 \mathrm{mM}$ tris-HCl-buffer ( $\mathrm{pH}$ 7.4), was prepared using a homogenizer. The supernatant of the homogenate, prepared by ultracentrifugation for $10 \mathrm{~min}$ at $3000 \mathrm{~g}$ was used for measurement of enzyme activities. Determinations of the enzymes activities were defined by standard methods, concentration was measured by spectrophotometer SP-46/ photo colorimeter KFK3 ${ }^{11}$. The splitting of rectus femoris muscle tissue and heart muscle tissue with $30 \%$ solution of $\mathrm{KOH}$, followed by the addition of ethanol and cooling, caused the precipitation of glycogen. Glycogen hydrolyzed by sulfuric acid to glucose, which is indicated by glycogen content ${ }^{12}$.

Total protein determination (according to Lowry) was performed according to the process described by Gudumac and coauthors ${ }^{11,13}$.
Statistical analysis was performed using Statistica 10 StatSoft Inc. With the purpose of determination of an adequate method of statistical estimation of the average difference between the study groups, preliminary check of distribution quantities in samples was held. According to Shapiro-Wilk criteria, which are used to assess the normality of distribution in the sample volume $n \leq 50$, all the samples did not receive data on deviation of the distribution of samples from normal $(\mathrm{P}>0.05)$. Given these data, the use of Mann-Whitney test was considered sufficient for valid conclusions. Differences were considered to be statistically significant at $\mathrm{P} \leq 0.05^{14,15}$.

\section{Results AND DISCUSSION}

Uncontrolled insulin-dependent DM leads to increased hepatic glucose output (Fig. 3).

Melatonin injections caused a sharp decrease by $52 \%$ and normalization (on $19^{\text {th }}$ day) of the elevated serum glucose level in DM group of rats compared with BG level before treatment. This can be explained by that fact that melatonin stimulates glucose transport to skeletal muscle cells via insulin receptor substrate-1/ phosphoinositide 3-kinase (IRS-1/ PI-3-kinase) pathway, which implies, at the molecular level, its role in glucose homeostasis and possibly in diabetes. Additionally, exposure to light at night and aging, both of which lower endogenous melatonin levels, may contribute to the incidence and/or development of diabetes ${ }^{16}$.

PK is the enzyme that catalyses the final step of glycolysis. It catalyses the transfer of a phosphate group from phosphoenolpyruvate (PEP) to adenosine diphosphate (ADP), yielding one molecule of pyruvate and one molecule of ATP. According to our 


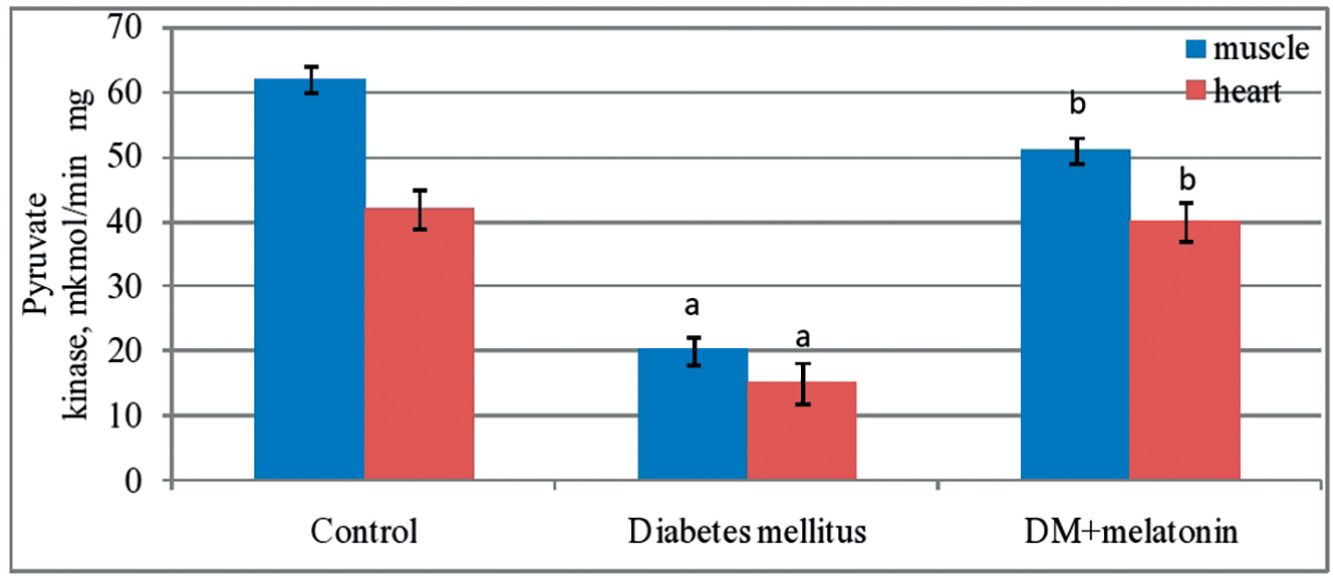

Figure 4. Pyruvate-kinase, $\mathrm{mkmol} / \mathrm{min} \times \mathrm{mg}$ in muscles and heart $(\mathrm{n}=6, \mathrm{x} \pm \mathrm{Sx})$ : 1. $a, b$ - changes are reliable $(\mathrm{p} \leq 0.05)$. 2 . $a$ - concerning control rats; $\mathrm{b}$ - concerning rats with diabetes mellitus.

results (Fig. 4), the activity of PK in muscle and heart tissue of alloxan diabetic animals were $45 \%$ and $63 \%$ less than in control group. It can be explained by low uptake of glucose from the blood to muscle tissue in the absence of insulin. Insulin stimulates glucose uptake, in particular in adipose tissue and skeletal muscle. This is accomplished by insulin-mediated movement of glucose transporting proteins to the plasma membrane of these tissues. Reduced glucose uptake by peripheral tissues in turn leads to a reduced rate of glucose metabolism. That means reduction of substrate for next catabolic changes in glycolysis. In addition, the activity of PK is regulated by insulin. We found that the activity of PK was normalized by introducing of melatonin $10 \mathrm{mg} / \mathrm{kg}$ of b.w. So, the activity of $\mathrm{PK}$ is reduced during DM, and the administration of melatonin leads to increasing its activity, probably due to direct activation of gene expression of glucose transporter GLUT 4, 2, 1 17,18.

The effects of melatonin on insulin secretion are mediated through the melatonin receptors (MT1 and MT2). It decreases insulin secretion by inhibiting cAMP and cGMP pathways, but activates the phospholipase $\mathrm{C} / \mathrm{IP} 3$ pathway, which mobilizes $\mathrm{Ca}^{2+}$ from organelles and, consequently, increases insulin secretion. Probably, melatonin enhances the uptake of glucose to muscles and activates PK activity by influencing the insulin secretion or direct $t^{19}$.

Some authors describe the fact that the kidneys contribute to glucose homeostasis through the processes of gluconeogenesis, glucose filtration, glucose reabsorption, and glucose consumption ${ }^{11}$.

In humans, only liver and kidneys contain significant amounts of the enzyme G-6-Phase and therefore are the only organs able to perform gluconeogenesis. Catecholamines normally exert direct effects on renal glucose release, although only they may indirectly affect both hepatic and renal glucose release by increasing availability of gluconeogenic substrates by suppressing insulin secretion.

In accordance to our results (Fig. 5) obtained in kidneys and liver of diabetic rats, the activity of G-6-phosphatase was increased in average by $148 \%$ compared with control value. Reduced activity of G-6-phosphatase in alloxan diabetic rats under melatonin action, that is demonstrated by our results, is probably due to the fact that melatonin is in the physiological counteraction with cortisone. Increased concentration of corticosterone and 11-dehydrocorticosterone was found ${ }^{20}$ in the serum of rats with alloxan-induced diabetes. Melatonin at a dose of 4 $\mathrm{mg} / \mathrm{kg}$ inhibited pyridoxal-induced glycogenolysis and reduced hyperglycemia due to reduced levels of catecholamines in blood plasma ${ }^{21}$.

Thus, melatonin has the potential to regulate glucose homeostasis through decreased gluconeogenesis in kidneys and liver of diabetic rats.

Diabetes may cause myocardial cell damage and eventually lead to the development of diabetic cardiomyopathy (DCM). DCM is a disease caused by diabetes that is independent of coronary artery disease, hypertension and heart valve disease. The main characteristics of DCM include oxidative stress, cardiac hypertrophy, apoptosis, myocardial fibrosis and impaired cardiac function ${ }^{12}$. Melatonin, a potent antioxidant agent, is essential for glucose homeostasis and regulation.

Therefore, the goal of the present study was to investigate the effects of melatonin against DCM in a rat model of diabetes and its possible mechanism. 


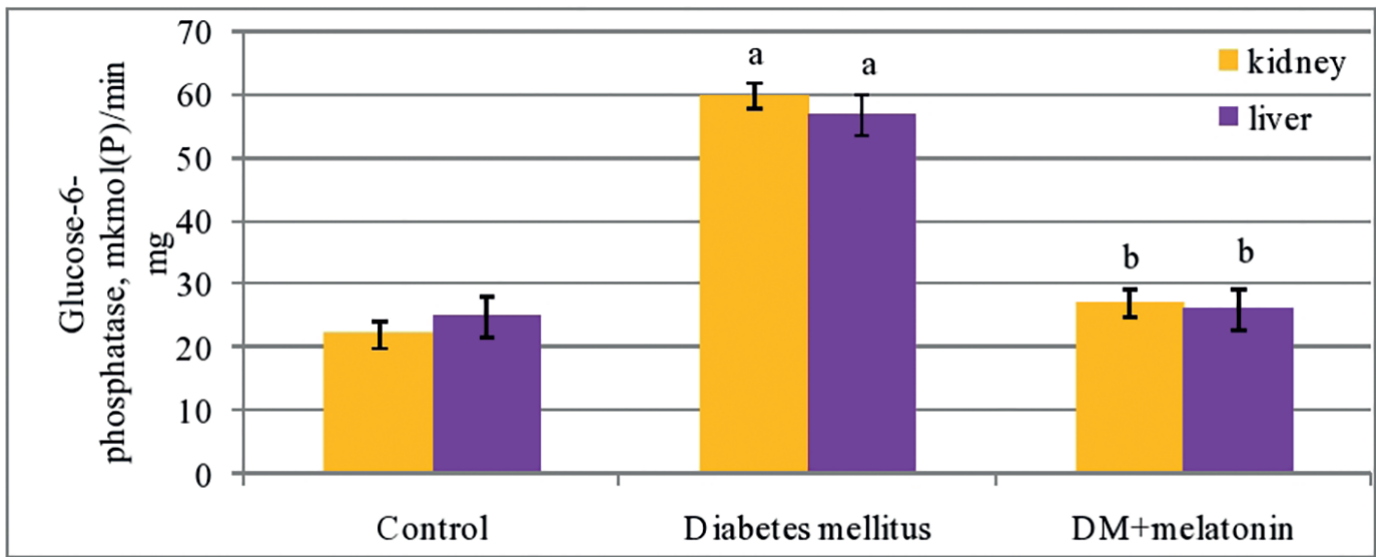

Figure 5. Glucose-6-phosphatase, $\mathrm{mkmol} / \mathrm{min} \times \operatorname{mg}(n=6, x \pm S x)$ :

1. $a, b$ - changes are reliable $(p \leq 0,05)$. 2 . a - concerning intact rats; $b$ - concerning rats with diabetes mellitus.

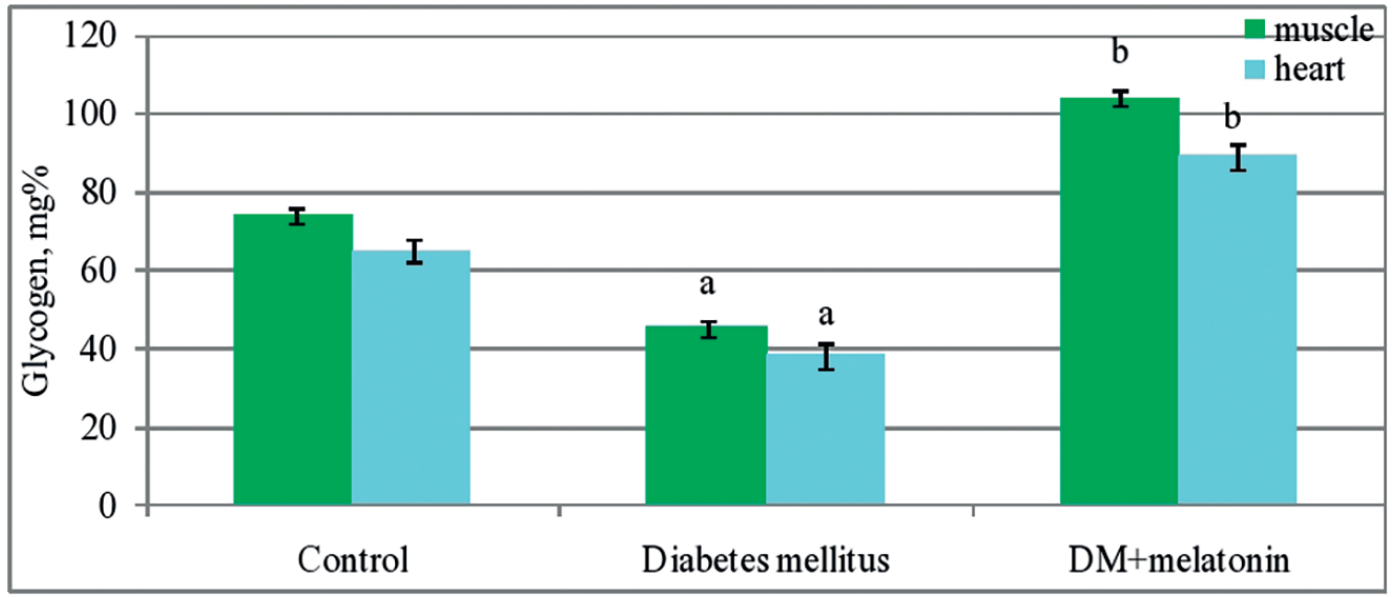

Figure 6. Glycogen, $\mathrm{mg} \%(\mathrm{n}=6, \mathrm{x} \pm \mathrm{Sx})$ :

1. $a, b$ - changes are reliable $(p \leq 0.05)$. 2 . $a$ - concerning intact rats; $b$ - concerning rats with diabetes mellitus.

We have established a reduction of glycogen (Fig. 6) in the heart and skeleton muscles of diabetic animals in average by $20 \%$ compared with the control.

Such changes are likely to occur due to a decrease in levels of glucose in heart muscle tissue and inhibition of its use. According to our research, 2 weeks of daily administration of melatonin to diabetic rats at $10 \mathrm{mg} / \mathrm{kg}$ of b.w. resulted in normalization of heart muscle glycogen content. The positive impact of melatonin was probably mediated by improving the glucose utilization, due to increased capture of tissues and activating major enzymes of glycogenesis ${ }^{22}$.

The possible link between melatonin and insulin interaction may be in its protective effect against free radical attack of $\beta$-cells Langerhans islets in pancreas. We carried out investigations of Langerhans islets in our previous studies ${ }^{23}$. Histomorphological alterations in Langerhans islets of pancreas in diabetic rats were recorded: their share decreased reliably by $55 \%$, the number of beta-cells decreased by $90 \%$, percentage of beta-cells with necrosis was $97 \%$ compared respectively with the indices of control animals. Melatonin treatment caused a sharp decrease in the elevated serum glucose and partial regeneration/proliferation of beta-cells of islets. It is concluded that the hypoglycemic action of melatonin could be partly due to amelioration in the beta-cells of pancreatic islets.

\section{Conclusions}

These findings suggest that melatonin reverses the catabolic consequences of total lack of insulin, by potentially decreasing of basal glucose level in the blood, increasing pyruvate-kinase activity and glycogen content in skeletal and heart muscles and suppressing the glucose-6-phosphatase activity in liver and kidneys of alloxan diabetic rats. This restores the events in Cori cycle by possible activation of glycolysis 
and glycogenesis in skeletal and heart muscles and causes normalization of gluconeogenesis in liver and kidneys.

\section{Compliance with Ethics Requirements:}

„The authors declare no conflict of interest regarding this article"

„The authors declare that all the procedures and experiments of this study respect the Rules of the work using experimental animals (1977) and the Council of Europe Convention on the Protection of Vertebrate Animals used in experiments and other scientific purposes (Strasbourg, 1986), according to directions of International Committee of Medical Journals Editors (ICMJE), as well as "Bioethical expertise of preclinical and other scientific research conducted on animals" (Kyiv, 2006). "

\section{References}

1. Rahimi-Madiseh M, Malekpour-Tehrani A, Bahmani M, Rafieian-Kopaei M. The research and development on the antioxidants in prevention of diabetic complications. Asian Pac J Trop Med. 2016; 9(9):825-831.

2. Lenzen S. The mechanisms of alloxan- and streptozotocin-induced diabetes. Diabetologia. 2008; 51(2):216-226.

3. Tang L, Li N, Jian W, Kang Y, Yin B, Sun S, Guo J, Sun L, Ta D. Low-intensity pulsed ultrasound prevents muscle atrophy induced by type 1 diabetes in rats. Skelet Muscle. 2017; 7(1):29.

4. Carrillo-Vico A, Guerrero JM, Lardone PJ, Reiter RJ. A review of the multiple actions of melatonin on the immune system. Endocrine. 2005; 27(2):189-200.

5. Mayo JC, Sainz RM, Tan DX, et al. Anti-inflammatory actions of melatonin and its metabolites, N1-acetyl-N2-formyl-5-methoxykynuramine (AFMK) and N1-acetyl-5-methoxykynuramine (AMK), in macrophages. J Neuroimmunol. 2005;165(1-2):139-149.

6. Rodriguez C, Mayo JC, Sainz RM, et al. Regulation of antioxidant enzymes: a significant role for melatonin. J Pineal Res. 2004;36(1):1-9.

7. Nelson DL, Cox MM. Lehninger: Principles of Biochemistry, Fourth Edition. New York, W.H. Freeman and Company, 2005: 340 .

8. Cano N. Bench-to-bedside review: Glucose production from the kidneys. Crit Care. 2002;6(4):317-321.
9. Gupta V, Bamezai RN. Human pyruvate kinase M2: a multifunctional protein. Protein Science. 2010; 19(11):2031-44.

10. Ghosh A, Shieh JJ, Pan CJ, Sun MS, Chou JY. The catalytic center of glucose-6-phosphatase. HIS176 is the nucleophile forming the phosphohistidine-enzyme intermediate during catalysis. The Journal of Biological Chemistry. 2002;277 (36):32837-42.

11. Kushnir OYu, Yaremii IM, Shvetsv VI, Shvets NV. Influence of melatonin on carbohydrate metabolism in the kidneys of alloxan diabetic rats. Fiziol. Journ. 2017;63(4):64 - 71.

12. Heather R. Cross, Lionel H. Opie, George K. Radda, Kieran Clarke. Is a high glycogen content beneficial or detrimental to the ischemic rat heart? Circulation Research. 1996;78:482491.

13. Ceban E, Banov P, Galescu A, Botnari V. Oxidative stress and antioxidant status in patients with complicated urolithiasis. J Med Life. 2016;9(3):259-262.

14. Singh J, Kakkar P. Antihyperglycemic and antioxidant effect of Berberis aristata root extract and its role in regulating carbohydrate metabolism in diabetic rats. J Ethnopharmacol. 2009;123(1):22-26

15. Vlasova SN, Shabunina EI, Pereslegina IA. The activity of glutathione-dependent enzymes of erythrocytes in chronic liver diseases in children. Laboratory Matter. 1990;8:19-21.

16. Pantsiuk K, Kushnir O. Changes of pyruvate kinase activity in the muscle tissue of rats under conditions of alloxan diabetes and administration of melatonin. Przeglad Lekarski. 2017; 74(1):107.

17. Pantsiuk K, Kushnir O. Influence of melatonin on the activity of glucose-6-phosphatase activity in kidneys of alloxan diabetic rats. Abstract book of International Student Congress (May 31 $1^{\text {st }}$ June 2 $2^{\text {nd }}, 2018$ Graz, Austria). 2018;96.

18. Lin GJ, Huang SH, Chen YW, et al. Melatonin prolongs islet graft survival in diabetic NOD mice. J Pineal Res. 2009; 47(3):284-292.

19. Selyatitskaya VG, Cherkasova OP, Pankina TV, Palchikova NA. Functional state of adrenocortical system in rats with manifest alloxan-induced diabetes mellitus. Bull Exp Biol Med. 2008; 146(6):708-710.

20. Budhram R, Lau-Cam CA. Attenuating effect of melatonin on pyridoxal-stimulated release of adrenomedullary catecholamines in the rat. Life Sciences. 2009;84(19-20):696-704.

21. Ha E, Yim SV, Chung JH, et al. Melatonin stimulates glucose transport via insulin receptor substrate-1/phosphatidylinositol 3-kinase pathway in C2C12 murine skeletal muscle cells. J Pineal Res. 2006;41(1):67-72.

22. Peschke E, Stumpf I, Bazwinsky I, Litvak L, Dralle H, Mühlbauer E. Melatonin and type 2 diabetes - a possible link? J Pineal Res. 2007;42(4):350-8.

23. Kushnir A, Davydenko I. Influence of melatonin on condition of the Langerhans islets of the pancreas in alloxan diabetic rats. World of Medicine and Biology. 2009; 5(4):31-35. 